\title{
Wenera w krzywym zwierciadle. O powinowactwach satyry, ironii i erotyki w literaturze wieków dawnych
}

\author{
Iwona Maciejewska
}


nAPTS Seria XIV 2008

\section{Iwona Maciejewska}

\section{Wenera w krzywym zwierciadle. O powinowactwach satyry, ironii i erotyki w literaturze wieków dawnych}

$S^{\text {twierdzenie autorstwa Juwenalisa: }}$

Wszystko, co robią ludzie - gniew, strach, żądza, sprzeczki, Ból, radość — oto pokarm dla mojej książeczki ${ }^{1}$ -

przywołane przez Paulinę Buchwald-Pelcową w monografii poświęconej satyrze czasów saskich, oddaje w sposób uogólniony i przy tym wielce trafny krąg zainteresowań literatury odbijającej rzeczywistość w krzywym zwierciadle. W ciągu wyliczeniowym niepoślednie - trzecie miejsce zajmuje żądza, która jakże często steruje poczynaniami człowieka. Rozumiana oczywiście na wiele sposobów. Pragniemy sławy, pieniędzy, zaszczytów, drugiego człowieka, gdyż, mówiąc słowami Sępa Szarzyńskiego - myśli nasze „żądzą zwiedzione [...] cukrują nazbyt rzeczy one, / które i mienić, i muszą sie psować”?.

W naturze ludzkiej, niedoskonałej i zmysłowej, leży wieczna pogoń za zludami tego świata, wśród nich za „stworzonym pięknymi obliczem”, gdyż miłość to „własny bieg bycia naszego"3. Twórcy literatury od zawsze dążą do oddania istoty tego skomplikowanego uczucia. Wśród milionów wierszy, wersów i strof, powstałych przez stulecia, odnajdziemy te gloryfikujące piękno miłości, eksponujące przede wszystkim jej duchową stronę, moc udoskonalania człowieka, sposób na zbliżenie się do Absolutu, ale

1 Cyt. za: P. Buchwald-Pelcowa, Satyra czasów saskich, Wrocław 1969, s. 58.

2 M. Sęp Szarzyński, Sonet V, w: idem, Poezje, wst. i opr. J. S. Gruchała, Kraków 1997, s. 72-73.

${ }^{3}$ Ibidem, s. 73. 
na przeciwległym krańcu spotkamy równie liczne teksty, które koncentrują się wyłącznie na fizycznym, zmyslowym aspekcie ludzkich związków. Czynią to na wiele sposobów: $\mathrm{z}$ jednej strony aprobatywnie, widząc w erotyce ważny, podstawowy aspekt codzienności, z drugiej zaś, co szczególnie charakterystyczne dla wieków dawnych, upatrują w fizycznym zbliżeniu źródło zła, grzechu, nieczystości.

W tej ostatniej postawie należy szukać korzeni satyrycznego ujmowania tematyki erotycznej w piśmiennictwie staropolskim. Krytyka, negacja i ośmieszenie erotycznych zachowań czlowieka raz po raz przewija się przez karty ówczesnej literatury, objawiając się z różnym stopniem natężenia w wielu gatunkach, takich jak fraszka, facecja czy satyra sensu stricto. Oczywiście nie zawsze zmysłowe igraszki są obiektem potępienia, często ich prezentacja spełnia czysto ludyczne funkcje. Treści obsceniczne, tak częste w dawnej kulturze, zarówno elitarnej, jak i plebejskiej, służą wielokrotnie po prostu dobrej zabawie. Prezentowane w formie żartobliwej, zaspokajają odwieczną potrzebę śmiechu, a zarazem odpowiadają na zawsze nam towarzyszące zainteresowanie ludzką seksualnością, która i dziś jest wszak tematem niezliczonych dowcipów.

Analiza, z konieczności wybiórcza, literatury epok dawnych pokazuje wyraziście, iż w sferze różnorakich erotycznych zachowań człowieka są takie, które szczególnie chętnie i często odbijano w krzywym zwierciadle satyry. Niewątpliwie ulubionym tematem krytycznych komentarzy są związki łączące ludzi o znacznej różnicy wieku i wynikające z nich przeróżne erotyczne perturbacje. Wielu staropolskich twórców dla podstarzałych amantów i zalotnic nie ma ni krztyny litości, bez skrupułów, a niejednokrotnie wręcz z perfidią opisując ich zmagania na "Wenerzynym placu”.

Stopień satyrycznej zjadliwości bywa różny, począwszy od ironicznie i aluzyjnie skomentowanych skutków takowych związków, po dosadnie i plastycznie skonstruowane obrazy, pełne naturalistycznych szczegółów. I tak subtelny Jan Gawiński w swych Dworzankach z przekąsem powie o niejakim Bornku starym młoda żone pojmującym, że

[...] my go chwalić musim $z$ tego,

Że fundusz czyni dla człeka młodszego ${ }^{5}$,

podczas gdy często nieprzebierający w słowach Wacław Potocki do staruszka zwróci się już bez tej uprzejmości, wierszem przypominającym rytmem i stylistyką Bakowskie Uwagi śmierci niechybnej:

Miły bzydku,

Po trzewiku

Lepiej siusiać sobie,

${ }^{4}$ A. Korczyński, Wizerunk złocistej przyjaźnia zdrady, wyd. R. Grześkowiak, Warszawa 2000, s. 23.

${ }^{5} \mathrm{~J}$. Gawiński, Dworzanki albo epigramata polskie, wyd. J. Głażewski, Warszawa 2005, s. 66. 


\section{$\mathrm{Niz}$ kto iny \\ Oskominy \\ Ma zbierać przy tobie 6 .}

Trzeba przy tym podkreślić, że w Ogrodzie nie plewionym wiersze o związkach starych z młodymi znajdziemy niezwykle często; autor powraca do tego widać mocno go drażniącego problemu po wielekroć, nie szczędząc krytyki amatorom zalotów w późnym wieku, jak też tym młodym, którzy dla majątku zawierają związki ze „szpetnostarymi”. Według poety ciężki to grzech, przynoszący tylko wstyd i zgorszenie, gdyż żadna ze stron nie odnosi w takich mariażach korzyści, a wręcz przeciwnie, kończą się one żałośnie. Staruszkowie nad grobem, niepanujący nad odruchami fizjologicznymi ${ }^{7}$, za wszelką cenę starający się przypodobać młodym wybrankom, narażają się na śmieszność i żenujące sytuacje, które autor komentuje zgryźliwie:

Struż się do trzeciej skory, snaż się, jak chcesz, dziadku,

Być tobie po staremu u śmiertuszki w zadku',

${ }^{6}$ W Potocki, Stary z młoda, w: idem, Dzieła, t. 2: Ogród nie plewiony i inne utwory $z$ lat 1677-1695, opr. L. Kukulski, Warszawa 1987, s. 583.

${ }^{7}$ Drastyczne obrazy spotykamy u Potockiego, który tak opisuje uderzającego w konkury starca:

Szedł do panien w komendy jeden wdowiec stary;

Miał tę wadẹ, że wnętrznej nie mógł trzymać pary.

Łomie przetarte fałdy, a co się ukłoni,

Jako $z$ woru upuści nieprzyjemnej woni.

I piżmo nie poradzi, na psa trudno składać,

Bo go nie masz, a ten bździ, że ledwie dosiadać

Mogą damy, gorszego nie trzeba wychodu;

Kropią izbę dla prochu, kadźcież też dla smrodu.

Tylko że się nie usra $[\ldots]$.

Swoje zachowanie chętny do amorów dziadek komentuje gorzko, ale z dosadną szczerością:

Komu lata dokucza, stare to nowiny,

Wenus grzeje, a miłość obraca się w bździny

(W. Potocki, Na starego wdowca komplementy, w: idem, Dzieta, op. cit., s. 26).

U Opalińskiego z kolei podstarzały żonkoś może usłyszeć od swej połowicy całą litanię obelżywych zarzutów:

Że śmierdzisz trupem zgniłym i że-ć z nosa ciecze,

Że oczy oparzyste ustawicznie płaczą,

Że zębów w gębie nie masz, żeś grzyb na pół zgniły.

(K. Opaliński, Na tych, co się $w$ zeszłym wieku żeniq, w: idem, Satyry, opr. L. Eustachiewicz, Wrocław 1953, BN I 147, s. 30).

${ }^{8}$ W. Potocki, Stary golec w' komendy, w: idem, Dzieła, op. cit., s. 171. 
jednocześnie stwierdzając wielce dobitnie:

A wszakem cię przestrzegał, mój sąsiedzie, szczerze:

Uczyń w lat siedmidziesiąt $z$ Wenerą przymierze.

Dotąd ze dzbanem chodzą, aże się też urwie,

I tyś dzisiejszej nocy dał garło na kurwie.

Lepsza, chociaż niemłoda, chociaż żona chuda;

Nigdy się długo młoda staremu nie uda'.

Jeszcze większe oburzenie wywołuje postępowanie młodych, sprzedających się dla majątku:

Im większy grzech, tym go też cięższą plagą karzą.

Żeś stare babsko i z tak szpetną pojąl twarzą,

Jako trupa, na większe przegniłego poły,

Musiałeś zgrzeszyć $z$ diabłem i jego anioły; [...]

Bo niechaj ci pieniądze same oknem lażą,

Nieznośnego i duszy smrodu nie odrażąa

Obiektem zjadliwej, satyrycznej przygany wielce często w staropolszczyźnie bywają ciągle chętne do miłosnych rozkoszy „staroduby”, czyli podstarzałe, głupie baby, o których ironicznie pisze Krzysztof Opaliński:

Gdy się babuś wymuszcze, gdy brwi ufarbuje,

Lecz hebanowych ząbków ufarbować trudno

I owych zmarszczków ująć, które poorały

Szpetną twarz ${ }^{11}$.

Mimo iż „przez włosy gęsto się przebija śron biały”, podstarzała zalotnica wciąż jest „psów niesyta”'2, jak domowa swacha z Żeńców Szymona Szymonowica, która omal nie szaleje na widok młodych parobków. Ale szanse takich amantek, „bżdżących się od wielkiej milości”, od której nieraz nabawią się francy, Potocki komentuje bezlitośnie:

Nie pomogą perfumy i perłowe tkanki,

Kiedy iskra doleci zgniłej grochowianki ${ }^{13}$.

${ }_{9}$ Idem, Do sasiada, w: idem, Dzieła, t. 1: Transakcja wojny chocimskiej $i$ inne utwory z lat 1669-1680, opr.

L. Kukulski, słowo wst. B. Otwinowska, Warszawa 1987, s. 347-348.

${ }^{10}$ Idem, Do mtodego szpetnostarej żony męża, w: idem, Dzieła, t. 2, op. cit., s. 378-379.

${ }^{11} \mathrm{~K}$. Opaliński, Na tych, co się w zeszlym wieku żeniq, w: idem, Satyry, op. cit., s. 31.

12 Sz. Szymonowic, Sielanki i pozostałe uiersze polskie, wst. i opr. J. Pelc, Wrocław 2000 (BN I 182), s. 169.

${ }^{13}$ W. Potocki, Baba w kominie, w: idem, Dzieła, t. 2, op. cit., s. 525. 
Starość to czas, w którym na erotyczne igraszki nie ma już miejsca. Tak przynamniej zazwyczaj twierdzą staropolscy moraliści, a ich naśmiewaniu się z wiekowych kochanków prawie zawsze towarzyszy satyryczna przygana ${ }^{14}$. I choć zdarzają się opinie podobne do tej wyrażonej we fraszce Do dziewki z Ksiag trzecich Jana Kochanowskiego, jakoby „im kot starszy, tym [...] ogon jego twarszy”15, to jednak głośniej brzmią głosy krytyczne wobec spóźnionych amorów.

Twórcy nie oszczędzają nawet samych siebie, komentując swe nadwątlone czasem siły witalne. Odważnie w tej kwestii i ze sporą dawką autoironii wypowiada się Elżbieta Drużbacka, oceniając szanse swego związku z ukrywającym się pod imieniem Tyrsysa pułkownikiem Wojciechem Jakubowskim ${ }^{16}$ :

Nie pracuj Kupidynie nad Tyrsym z Filidą,

Bo już w stopień miłości gorącej nie wnijdą.

Ustała w tych amantach Wenerze ofiara:

Tyrsy ostygł, a Filis do amorów stara.

Zaleć raczej bożkowi, co się zna na lekach,

Niechaj ziela tęgości wyszuka w aptekach.

Cud uczynisz, gdy w Tyrsym wigor mdly odrodzisz,

Filidę w pięciudziesiąt kilku lat odmłodzisz ${ }^{17}$.

Z kolei Potocki komentuje rzekome nagabywania znajomych, by powtórnie się ożenil, z właściwą sobie dosadnością:

Moi panowie, rzekę owym sąsiadom,

Lepiej ci ja, niźli wy, mej naturze wiadom;

Dla Wenery, co mię raz ledwie w miesiąc rusza,

Ustawicznie się piorąc, siedzieć u folusza?

Wolę tak dożyć wdowcem, panienki nie zdradzać,

Wolnym być sobie, $z$ babą domu nie zasmradzać ${ }^{18}$.

Przy okazji owych dywagacji o seksualnej sprawności napotykamy liczne aluzyjne określenia zarówno męskich, jak i kobiecych narządów płciowych, bardziej bądź mniej

\footnotetext{
${ }^{14}$ Por. Z. Kuchowicz, Wiek w miłości, w: idem, Mitość staropolska. Wzory - uczuciowośt - obyczaje erotyczne XVI - XVIII wieku, Łódź 1982, s. 395-411.

${ }^{15}$ J. Kochanowski, Fraszki, opr. J. Pelc, Wrocław 1991 (BN I 163), s. 157.

${ }_{16}$ O okolicznościach towarzyszących powstaniu tych utworów zob. K. Stasiewicz, Elżbieta Drużbacka. Najuybitniejsza poetka czasów saskich, Olsztyn 1992, s. 51-52.

17 E. Drużbacka, Na przestadowanie pod imieniem Tyrsys i Filis, w: eadem, Wiersze wybrane, wst. i opr. K. Stasiewicz, Warszawa 2003, s. 73.

${ }^{18}$ W. Potocki, Starego ożenienie, w: idem, Dzieła, t. 2, op. cit., s. 460.
} 
rozpowszechnione w ówczesnym języku erotycznym, począwszy od „korzenia”19, obecnego już wszak we fraszkach Jana Kochanowskiego, poprzez „rożen”, „wierzbowy sworzen”, „suchy konar”, „kurek” przykładany do panewki, „wątor”, „przegiętkę”, aż po „nos”, który to wielce zawiesisty spowodowal w Wizerunku ztocistej przyjaźniq $z d r a d y$ Adama Korczyńskiego, że pewna Wloszka zdradziła swego starego męża z młodym, urodziwym Polakiem. Zresztą autor tegoż utworu nie jest szczególnie skłonny, by tę niewierność potępić, zaś małżonka, który „latom nie miał miary”20, a wziął sobie młodą żonę, nazywa wprost „durniem starym” "21, bo wszak, mówiąc słowami Gawińskiego:

W stary wóz konie zaprząga szalone, gdy stary młodą pojmuje żonę 22 .

Jak widać, zdrada w małżeństwie bywa w literaturze dawnej traktowana ambiwalentnie i nie zawsze a priori potępiana, choć oczywiście grzech nieczystości to jeden z najczęstszych tematów satyrycznych obrazków ${ }^{23}$. Z jednej więc strony mamy liczne historyjki o erotycznych schadzkach bab, chłopów, księży itd. opowiadane wyłącznie gwoli dobrej myśli, bez wyrazistej moralnej przygany, ale $z$ drugiej napotykamy liczne głosy grzmiące oburzeniem, pelne inwektyw i typowej dla satyry przesady. Celuje w tym Krzysztof Opaliński, dla którego znalezienie dobrej i wiernej małżonki graniczy z cudem, bo każda panienka już od dziecka przywyka do nocnych wizyt adoratorów, którzy „znajdą ją na łóżeczku i coś namacają" ${ }^{24}$, już jako dorosła ciągle „się z gachy lize i przy małżonku samym" ${ }^{25}$, który, nawiasem mówiąc, często przymyka na to oczy, gdy wcześniej połowica wniosła dobry posag. Bardziej elegancko podobne przekonanie o moralności płci pięknej wyraża Gawiński, który wspomina, iż ptak Porfiryjo, będący strażnikiem cnoty każdej małżonki, jest bliski wyginięcia, bo jeden przedstawiciel tego osobliwego gatunku umiera za każdym razem, gdy jakaś białogłowa przyprawi mężowi rogi.

Cudzolóstwo, erotyczne rozpasanie, miłosne trójkąty, niedobrane związki podlegają satyrycznemu opisowi nie tylko wtedy, gdy mają służyć naprawieniu obyczajów

${ }^{19}$ Drużbacka wielce złośliwie komentuje stan męskości wzdychającego do Filis Tyrsisa:

Któraż się zwiędłym bawić chce korzonkiem?

Kawałek szczupły, już przestały, miętki,

Niemasz co dzielić między pretendentki -

Wet za wet pewnemu kawaleroui od trzech dam, które wierszem swoim zaczepit (Jakubowski putkownik), w: eadem, Wiersze uybrane, op. cit., s. 77.

20 A. Korczyński, Wizerunk..., op. cit., s. 38.

${ }^{21}$ Ibidem, s. 151.

22 J. Gawiński, O nieróunym stadle, w: idem, Dworzanki..., op. cit., s. 126.

23 Zob. P. Buchwald-Pelcowa, Satyra czasów saskich, op. cit., s. 66-67.

${ }^{24}$ K. Opaliński, Na zepsowane stanu białogłowskiego obyczaje, w: idem, Satyry, op. cit., s. 64 (satyra II 1).

${ }^{25}$ Ibidem, s. 66. 
ogólnie rozumianej zbiorowości. Powyższe motywy bardzo chętnie wykorzystywane są również wówczas, gdy przedmiotem krytyki staje się konkretna postać lub grupa osób, a z taką sytuacją mamy do czynienia w wielce obfitej w wiekach dawnych okolicznościowej literaturze politycznej. Tego typu piśmiennictwo towarzyszyło

stale życiu społeczności szlacheckiej, nasilając się w momentach zewnętrznych czy wewnętrznych kryzysów, rosnąc w liczbie w trakcie takich wydarzeń jak bezkrólewia, konfederacje, wojny, ale reagując także na wypadki prywatne, które wywoływały jednak duze zainteresowanie opinii publicznej ${ }^{26}$,

zwłaszcza gdy dotyczyły person powszechnie znanych. W powyższej opinii Janusza Maciejewskiego w sposób syntetyczny zarysowane zostały impulsy sprzyjające rozwojowi literatury komentującej bieżące wypadki w państwie. W takiej twórczości żywioł satyry jest często wszechobecny, przejawia się między innymi pod postacią paszkwilu, który bywa nazywany satyrą imienną.

W walce przeciwstawnych racji wykorzystywane są przeróżne argumenty, które mają zdyskredytować wroga politycznego. Zarzuty bywają różnej rangi, począwszy od zdrady ojczyzny, tchórzostwa na polu walki, prywaty, korupcji, po odwoływanie się do zwykłych ludzkich słabostek, cech wyglądu czy oznak ułomności. Dogodnej broni szuka się również w interesującej nas tu sferze erotyki. Tajemnice alkowy są wyciągane bez skrupułów na światło dzienne, o ile można je wykorzystać w prowadzonej kampanii. Anonimowi często autorzy nie szczędzą krytyki najwyższym osobom w państwie, $z$ władcami i ich małżonkami włącznie. Przykładami służyć tu może chociażby literatura komentująca romanse Zygmunta Augusta i jego ślub z Barbarą Radziwiłłówną ${ }^{27}$, związki formalne i nieformalne Zygmunta III Wazy, głośne amory Sobieskiego z Marysieńką czy wreszcie liczne erotyczne podboje Augusta II Sasa ${ }^{28}$.

\footnotetext{
${ }^{26}$ J. Maciejewski, Wstęp do: Literatura barska, opr. J. Maciejewski, Wrocław 1976 (BN I 108), s. LXII.

${ }_{27}$ Zob. J. Nowak-Dłużewski, Okolicznościou'a poezja polityczna w Polsce. Czasy Zygmuntouskie, Warszawa 1966, s. 171-190.

${ }^{28}$ Zob. P. Buchwald-Pelcowa, Satyra czasów saskich, op. cit., s. 226 i S. Roszak, Duór warszawski a dwory provincji - między konfrontacja a potrzeba akceptacji, w: Dwory magnackie w XVIII wieku. Rola i znaczenie kulturotwórcze, red. T. Kostkiewiczowa, A. Roćko, Warszawa 2005. Autor przywołuje jeden z licznie obecnych na kartach sylw szlacheckich wierszyków, złośliwe komentujących romanse Augusta II. Ten poświęcony jest pierwszej polskiej metresie, Urszuli z Bokumów Lubomirskiej:
}
Król August Lubomirskim chcąc czynić nagrodę
Że im w dupie i z żupie wielką zrobił szkodę
Więc co ma najmilszego, tym ich kontentuje
Że im w związek małżeński swą kurwę daruje
Już że tedy praetextu nie miejcie o żupę
Macie i kiep za swą sól i dupę za dupę.

Cyt. za: S. Roszak, Dwór warszawski..., op. cit., s. 11. 
Zdarzało się tak, że to właśnie zaogniona politycznie sytuacja sprzyjała przypomnieniu i potępieniu jakiegoś faktu z życia osobistego monarchy. Znamienny jest tu choćby przykład Zygmunta III Wazy, który kolejno żenil się z dwiema siostrami Habsburżankami, najpierw z Anną, a po jej śmierci z Konstancją. Choć ten drugi mariaż nie podobał się przeciwnikom króla $\mathrm{z}$ obozu Zamoyskiego, to jednak, jak twierdzi Juliusz Nowak-Dłużewski, zrazu nie był on satyrycznie komentowany ${ }^{29}$. Sytuacja jednak zmienia się zasadniczo, gdy dochodzi do rokoszu Zebrzydowskiego. Wówczas polemiści atakujący władcę wypominają to ich zdaniem niegodne, kazirodcze małżeństwo. Padają wtedy ostre słowa, czyniące z Zygmunta zatwardziałego lubieżnika:

Wiele panien zgubieło wieńce swej czystości,

Dogadzając za wziątek twej chciwej lubości!

Wie Kraków o tem wszystkim i Łobzów wie o tem,

Wie, z Morawcową dziewką kto też drugi potem.

Wybujałeś z grzechów swych pańskiej powinności,

Udałeś się na równe ciała wszeteczności ${ }^{30}$.

Szczytem niegodziwości jest ów bezbożny związek:

A nasz mily pan Zygmunt zaż nie przeszedł wszytki

Żywotem swem smrodliwym sprośne wszeteczniki?

W gorszej, niż Sardanapal, rozpustności żyje,

Herodskie kazirodztwo, małżeństwem chuć kryje. [...]

W jakim małżeństwie mieszka ten to Zygmunt Trzeci.

Jak królową zwać mają Zygmuntowe dzieci:

Czy matką, czyli ciotką, czy jeszcze inaczej?

Patrz, królu, iż dać pokój temu było raczej.

A wżdy się jeszcze gniewa, iż mu prawdę mowią,

Kiedy go kazirodem, wszetecznikiem zowią ${ }^{31}$.

Podobnie niestosowny ożenek kilkadziesiąt lat później zostaje wypomniany ożenionemu z wdową po bracie Janowi Kazimierzowi, któremu jakiś zwolennik Lubomirskiego źle wróży:

Nie możesz już mieć szczęścia za wieku twojego:

Tak ci Bóg kazirodcę zwykl karać każdego ${ }^{32}$.

\footnotetext{
${ }^{29}$ Zob. J. Nowak-Dłużewski, Okolicznościowa poezja polityczna w Polsce. Zygmunt III, Warszawa 1971, s. 86.

${ }^{30}$ Sumnienie mówi, w: Pisma polityczne z czasów rokoszu Zebrzydowskiego, wyd. J. Czubek, t. 1, Kraków 1916, s. 12.

${ }^{31}$ Wotum Filopolitesa Prawdzickiego ..., w: ibidem, s. 289-290.

32 List do Króla JM. Jana Kazimierza na porażce ciepielowskiej..., w: Poezja Zwiąku Święconego i rokoszu Lubomirskiego, opr. J. Nowak Dłużewski, Wrocław 1953, s. 190.
} 
Autorzy paszkwilów nie szczędzili ostrych, niewybrednych słów głównym aktorom ówczesnej sceny politycznej, zwłaszcza gdy alkowiane sekrety stanowily tajemnicę poliszynela. Sobieskiego, który na wiele lat przed objęciem tronu związał się z zamężną Marysieńką, spotkało wiele kpin i przytyków, podobnie jak jego wybrankę, która dość ostentacyjnie pocieszała się po śmierci pierwszego małżonka:

Czy rada, czy też zdrada? Pewnie zdrada pieska:

W dzień wdowa i Zamoyska, skoro noc — Sobieska.

Sobieska, lubo płacze, ale ludziom gwoli:

Żywego, nie martwego niebożątko woli33 ${ }^{33}$

Maria Kazimiera, ironicznie określona mianem niebożątka, w innym utworze nazwana jest po prostu, uczciwszy uszy, kurwą, na którą Sobieski powinien mieć dobrego kija. Nie miała już wówczas przyszła królowa, tak jak i zresztą w przyszłości ${ }^{34}$, najlepszej opinii. Świadczy o tym inny anonimowy paszkwil, sugerujący, iż Sobieski, jako świeżo upieczony hetman polny i zarazem żonkoś niedługo po ślubie, nie radzi sobie na polu bitwy z Tatarami, bo musi parasolką zasłaniać sobie rogi. Rogaczem miał go rzekomo uczynić jurny prymas Prażmowski. Pomysł autora komentuje Juliusz Nowak-Dłużewski: „anonim chyba łże”, ale...

może tam gdzieś skrewiła ta Marysieńka, doskonałość tylko w oczach męża. [...] Należała do plutonu czepców dworek Ludwiki Marii, sprowadzanych $z$ Francji, a rozdawanych potem magnatom na żony dla umocnienia w Polsce zasad dworskiej polityki królowej ${ }^{35}$.

Nawiasem mówiąc, jeden z przywoływanych tu autorów domyśla się takiego właśnie źródła owego słynnego miłosnego związku.

Wspomniany wyżej Prażmowski to słynny Oczkoś, utrapienie wielu małżonków. Przez anonimowego zwolennika Związku Święconego nazywany jest zdrajcą, który miast szablą na polu bitwy, zaszczytów „dosługiwał się jajcy”36. Podobnie zdyskredytowany został zresztą i Sobieski, na którego spadły godności państwowe po buntowniku Lubomirskim, a według złośliwego autora przystoi mu tylko „w fraucymerze kręcić się z kiełbaską" ${ }^{37}$.

W paszkwilach szukających argumentów w sferze erotycznej chętnie wykorzystywane były odwolania do nazwisk bądź herbów ośmieszanych postaci. Przykładem

\footnotetext{
${ }^{33}$ Kunszt, w: ibidem, s. 210-211.

${ }^{34}$ Zob. P. Buchwald-Pelcowa, Satyra czasów saskich, op. cit., s. 182.

${ }^{35}$ J. Nowak-Dłużewski, Okolicznościowa poezja polityczna w Polsce. Dwaj królowie rodacy, Warszawa 1980, s. 25.

${ }^{36}$ Na Prażmowskiego, Kanderza Koronnego..., w: Poezja Związku Święconego i rokoszu Lubomirskiego, op. cit., s. 60.

${ }^{37}$ Wiersz o marszalkach, w: ibidem, s. 170.
} 
może służyć tu chociażby głośny romans (żonatego ze sporo od siebie starszą kuzynką) wojewody Adama Tarły z Anną Lubomirską, który zakończył się śmiercią adoratora w pojedynku z Kazimierzem Poniatowskim. Elżbieta Drużbacka, protegowana Czartoryskich, spłaca swój dług wobec opiekunów ${ }^{38}$, pisząc złośliwy utwór o niefortunnym końcu ich politycznego przeciwnika, oparty na erotyczno-biologicznym koncepcie odwołującym się do nazwiska głównego bohatera:

Tăro zjadło cię, Tarło, rzeka cię pożarła, Żeś innego, swe mając, właśnie szukał tarła.

Gdy w odnodze Śrzeniawy, nie chcąc swej milości.

Târłeś się, któż winien, żeś został na ości.

Trzeć się było w swym nurcie, nikt by nie przeszkodzil,

Choć nurt stary, lecz zawsze złoty piasek rodził. [...]

Ten go kanal zgubil, młodszych pragnąc rybek,

Wiedząc, że w starym nurcie nie będzie zarybek ${ }^{39}$.

Z kolei powstałe w okresie konfederacji barskiej utwory wymierzone przeciwko Stanisławowi Augustowi w sposób niewybredny komentują jego związek z carycą Katarzyną, wykorzystując odniesienia do herbu:

A gdzież miejsce jest dla Ciołka? Chyba przy ogonie

Położyć go dobrze jest. Niech między nogami

Buja sobie $z$ ogonem wzdartym i rogami. [...]

Król Ciołek, Prymas Baran, a cóż to za pora?

W tak spokojnym królestwie tak gziwa obora?40

Inny paszkwilant ze zgorszeniem i pełnym oburzenia zdziwieniem komentuje fakt, iż zwiedzione cielęta wybrały sobie króla-Ciołka:

Któryż to rozum ludzki pojąć może,

Nierządne w Moskwie co sprawiło łoże?41

Przykłady na wykorzystanie zarzutów natury erotycznej w satyrze politycznej wieków dawnych można by mnożyć, ale nie o to wszak chodzi, by epatować kolejnymi niewyszukanymi i często mocno obscenicznymi obrazami. Natomiast warto niewąt-

${ }^{38}$ Zob. K. Stasiewicz, Elżbieta Drużbacka..., op. cit., s. 58.

${ }^{39}$ E. Drużbacka, Refleksja nad śmiercia J. W.JMć pana Tarta, wojeu'ody lubelskiego herbu Topór..., w: eadem, Wiersze uybrane, op. cit., s. 96-97.

40 Aluzja do iluminacji J. W. Ks. Mości Radziwitła Marszatka Konfederacji Generalnej, w: Literatura barska, op. cit., s. 52-53.

${ }^{41}$ Wiersz $z$ paszkwilem ex allusione od imion i herbów 1768, w: ibidem, s. 81. 
pliwie zwrócić uwagę na jeszcze jeden sposób wykorzystania tego typu skojarzeń, który odnajdujemy w okolicznościowej poezji politycznej. Wiąże się on mianowicie z pewnym rozpowszechnionym wówczas chwytem literackim, opartym na personifikowaniu pojęć abstrakcyjnych, takich jak ojczyzna, wolność, sejm, czy religia. Jeśli dodatkowo wyposażano owe persony w zdolność przemawiania i powierzano im zadanie przedstawienia krytycznej sytuacji w państwie, można mówić o wykorzystaniu prozopopei, scharakteryzowanej już w antycznej teorii retorycznej.

Najbardziej rozpowszechnioną w dawnej literaturze politycznej upersonifikowaną postacią była ojczyzna, z której najczęściej czyniono matkę zatroskaną o los swych niewdzięcznych dzieci. Ten wizerunek ewoluował wraz z pogarszającym się stanem państwa - przydawano jej chorób, blizn, wrzodów, by wreszcie złożyć ją do grobu, jak w tekście Dominika Rudnickiego Lament prowincyj polskich nad umarłq matkq ojczyznq ${ }^{42}$. Jej uczłowieczone, cielesne oblicze doprowadziło jednego $z$ anonimowych twórców doby saskiej do dość osobliwego pomysłu artystycznego. Mowa tu o utworze Gwałt Polski z 1708 roku, który edytorsko opracowała Maria Eustachiewicz ${ }^{43}$. Nieznany autor odszedł w nim od najbardziej popularnej wizji ojczyzny jako matki, a zwrócił się w kierunku innego obecnego w ówczesnej literaturze obrazu, w którym Rzeczpospolita prezentowana była jako oblubienica ${ }^{44}$. Idąc tym tropem, twórca proponuje nam dość szokujący w swej wymowie koncept, w którym Polska to mało atrakcyjna dla ewentualnych konkurentów panna na wydaniu. Dlaczego jest tak niewiele warta? Wiersz tłumaczy to aż nadto dobitnie:

Podź Polsko za mąż, jeśliś dzieweczka! —

$\mathrm{O}$, nie pojdę, Francuzowie,

$\mathrm{O}$, nie pojdę, Holendrowie,

Bom nie caleczka.

Gwałt mi zrobili możni panowie,

Wzięli mi wianek Wolności

Dla swej zbytecznej hardości

Źli Sapiehowie. [...]

Skryłam się była w szlacheckim dworze,

Ali Sasi przyjechali,

${ }^{42}$ Zob. I. Maciejewska, „Tu leży matka królestw i królowa” - o ewolucji poetyckiego wizerunku zagrożonej Rzeczypospolitej, w: Między barokiem a oświeceniem. Wojny i niepokoje czasów saskich, red. K. Stasiewicz, S. Achremczyk, Olsztyn 2004, s.199-206.

${ }^{43}$ Zob. M. Eustachiewicz, „Gwałt Polski” — szkic z dziejów poezji politycznej epoki saskiej, „Ze Skarbca Kultury" 1986, z. 43.

${ }^{44}$ Zob. ibidem, s. 48-52. 


\section{Gwałt mi i tam udziałali Jawnie w komorze [...] \\ I Połaniecki podniósł mi kiecki \\ Tylkom mu powąchać dała, Inszej mu szukać kazała \\ W granicy szwedzkiej ${ }^{45}$.}

W tej dość obszernej tyradzie, napisanej przez zwolennika Stanisława Leszczyńskiego, w owym osobliwym zbiorowym gwałcie uczestniczą główni bohaterowie ówczesnej sceny politycznej - tekst nie jest więc uogólnioną satyrą, ale paszkwilem, którego autor sięgnął po bardzo drastyczną metodę obrazowania, aby pogrążyć przeciwników. Skądinąd pomysł ów do całkiem nowych nie należy, bo podobny, choć znaczniej mniej wyrazisty i skierowany nie przeciwko konkretnym osobom, odnajdujemy już w poezji z czasów rokoszu Zebrzydowskiego, gdzie pojawia się niesiona na rękach zgwałcona i zmarła córka Ojczyzny - Wolność, ale autor Votum zjazdów i rokoszu 1606 unika tak otwartego jak w przytoczonym powyżej tekście epatowania erotycznym kontekstem.

Powyższe refleksje pokazują, oczywiście tylko w pewnym zarysie, jak często sfera intymnych kontaktów ludzkich stawała się niegdyś źródłem satyrycznej przygany, pojawiającej się w tekstach o różnorodnym charakterze i służącej wielorakim celom artystyczno-ideowym. A ponieważ ludzie od wieków skłonni byli do grzechu przeciw szóstemu przykazaniu, tematów do opisu bystrym, przenikliwym obserwatorom nigdy nie brakowało - wystarczyło tylko uważnie spojrzeć w odbite w krzywym zwierciadle obrazki z naszej codzienności. 